\title{
CHANGES OF VENTRICULAR VECTOR DURING TRAINING OF THOROUGHBRED RACE HORSES
}

\author{
J. HANÁK \\ Department of Diagnostics, Therapy and Prophylaxis of Animal Diseases, University of Veterinary \\ Science, 61242 Brno
}

Dedicated to the 50th birthday of Prof. MVDr. P. Jagoš, CSc.

Received February 11, 1980

\begin{abstract}
Hanák J.: Changes of Ventricular Vector During Training of Thoroughbred Race Horses. Acta vet. Brno, 49, 1980: 211-216.

The influence of training upon the value of ventricular vector followed in 5 planes of the tetrahedron lead system has been examined on three experimental groups represented by 226 thoroughbred horses. It has been found that the training significantly decreases the magnitude of ventricular vector. The extent of this decrease depends both on the character of training and exploitation of horses. The phenomenon is ascribed to the development of so-called sport regulative dilatation of heart which increases the beat volume.
\end{abstract}

Horse, training, vectors, ECG.

The future conception of horse breeding till 1990 as proposed by Ministry of Agriculture of Czech and Slovak Republic expects not only qualitative and quantitative improvement of breeding material but also the increase in performance based on scientific approach to the training process. This situation in veterinary diagnostics somewhat resembles that in human medicine in the field of sport physiology. Apart from active health check of equestrian horses it is necessary to employ a series of modern diagnostic methods to monitor even the slightest clinico-physiological and biochemical changes in the organism of animal being trained. One of these methods is represented by electrocardiography with the classical or vector interpretation.

The influence of training on organism of trained horse has been studied from many points of view. Most of works concentrated on hematologico-biochemical factors, movement mechanics or radiotelemetry of cardiovascular and respiratory system. Relatively few authors, however, have studied the electrocardiographic changes induced by the training of equestrian and race horses (Steel 1963; Mill 1977; Illera et al. 1979 and others). These papers deal predominantly with the time dependence of ECG during horse training. Nobody, to our knowledge, has studied the influence of training upon the vectorcardiogram of a horse.

For several years we have studied not only the problems of equestrian horses training (Hanák 1978) but also the influence of various external and internal factors on the equine electrocardiogram. It has already been reported on the influence of age and body growth on ECG (Hanák 1979; 1980a; Hanák and Jagoš 1980), on characteristic features of so-called sport ECG of race horses (Hanák et al. 1976; Hanák 1979; Hanák and Jagoš 1980) and on the influence of genetic factors on ECG (Hanák and Žert 1980). Attention has also been paid to characteristic features of working ECG of equestrian horses taken telemetrically (Hanák 1980b).

It was the purpose of this work to monitor and give a vector interpretation of complex ECG changes which are induced by a long lasting training of thoroughbred race horses. The attention has, therefore, been focused to the value of ventricular vector. 
The influence of race-horse training on the changes of ventricular vector was followed on a total of 226 thoroughbred horses divided into three experimental groups.

First experimental group was represented by 20 horses of both sexes which were subjected to ECG examination prior to their transportation to the training centre. Their age was 17-20 months (yearlings). They were further followed in the course of the two-year training period, being examined after one year of training ( 2 years old) and after two years of training ( 3 years old).

Second experimental group consisted of 48 two-year old horses (trained for one year), 58 three-year old horses (trained for two years) and $\mathbf{4 0}$ four or more years old horses (trained for three and more years).

Third experimental group included 40 horses 17-20 months old (yearlings) before their departure to the training centre, 40 horses ( 4 and more years old) who had three and more years of training. These were taken from the second experimental set. Moreover, there were 20 thoroughbred mares who finished their racing career more than three years ago and were no longer trained, being used for breeding.

All examined horses exhibited distinct, well defined heart beats with no arrhythmias and additional murmurs. The horses did not show any clinical symptoms of disease during the experiments; they were fed normally and regularly trained since the age of 20 months.

The ECG records were taken on a Startest (Chirana) instrument applying a tetrahedron lead system (Hanák 1979) in horizontal (H), transversal (T), saggital right (Sr), saggital left (Sl) and saggital middle (Ss) planes which intersected the centre of tetrahedron. The vector interpretation of QRS ventricular complex was carried out by determining the value of ventricular vector in each plane usirg the cross diagram according to Holzmann (Perlick and Böhme 1967).

The results were statistically treated, tabulated and graphically evaluated. A method of simple variance analysis as well as the Duncan test were used to determine the significance of influence of training on the value of ventricular vector.

\section{Results}

During two years training of 1st experimental group a gradual decrease of ventricular vector value in all tetrahedron planes has been noted (see Table 1). The influence of training on this decrease in $\mathrm{T}$ and $\mathrm{Sl}$ planes was significant as early as after one year of training $(P<0.05)$ and became highly significant after two years of training $(P<0.01)$. The differences in values of this vector for different age groups $(2$ and 3 years) were also significant $(P<0.05)$ in these planes. One year lasting training does not, however, influence the ventricular vector value

Table 1

The value of ventricular vector during two-year training of 20 thoroughbred horses (mV)

\begin{tabular}{|c|c|c|c|}
\hline Plane & Before training & After one year & After two years \\
\hline $\mathbf{H}$ & $1.09 \pm 0.44$ & $0.95 \pm 0.22$ & $0.77 \pm 0.31$ \\
$\mathrm{~T}$ & $1.37 \pm 0.41$ & $1.07 \pm 0.49$ & $0.83 \pm 0.32$ \\
Sr & $1.31 \pm 0.42$ & $1.18 \pm 0.57$ & $0.97 \pm 0.27$ \\
S1 & $1.27 \pm 0.36$ & $1.01 \pm 0.37$ & $0.66 \pm 0.26$ \\
Ss & $1.63 \pm 0.32$ & $1.49 \pm 0.45$ & $1.20 \pm 0.40$ \\
\hline
\end{tabular}

in Sr and Ss planes $(P>0.05)$. 'A significant influence of training was noted in the $\mathrm{Sr}$ plane after two years $(P<0.05)$. The phenomenon was even more pronounced in the Ss plane $(P<0.01)$. In the latter plane there were also statistically significant differences $(P<0.05)$ in size of ventricular vector for different age groups ( 2 and 3 years). No influence of training upon the value of ventricular vector was observed in the $\mathrm{H}$ plane when using the above mentioned statistical method of evaluation $(P>0.05)$. 
Fig. 1

The value of ventricular vector in individual planes of tetrahedron in three age groups of horses

\section{2-year-old}

(trained for 1 year)

4- and more years old

(trained for 3 and more years)

3-year-old

(trained for 2 years)

Second experimental set also exhibited the decrease in the value of ventricular vector in all tetrahedron planes as a result of training process (see Fig. 1). The statistical significance of this decrease is, however, different for individual planes. In all respects of simple variance analysis the influence of training process duration and age

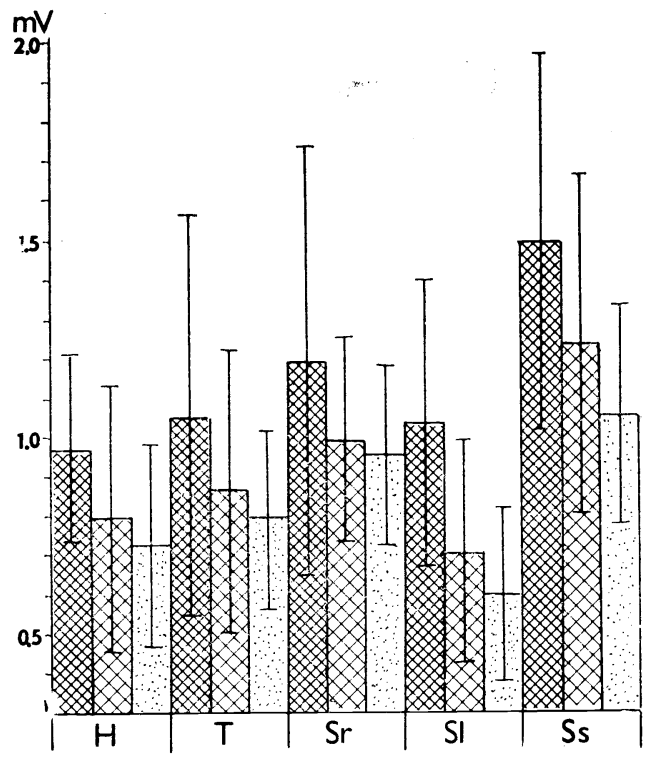
of animals was found statistically significant as far as the decrease of ventricular vector value in $S 1$ and Ss planes was concerned $(P<0.05)$. There are statistically significant variations in the $\mathrm{T}$ plane between 2 and 3 years old animals $(P<0.05)$ as well as between 2 and 4 years old horses. In the case of 3 and 4 years old groups the differences in ventricular vector value were found to be statistically insignificant $(P>0.05)$. There was a statistically significant difference between 2 and 4 years old groups $(P<0.05)$ as far as $\mathrm{H}$ and Sr planes were concerned while in other variations ( 2 years: 3 years, 3 years: 4 years) the influence of training duration on the vector decrease was found to be insignificant $(P>0.05)$. Long training (more than three years) lowers significantly the value of ventricular vector in all planes $(P<0.05)$.

Fig. 2

Changes of value of ventricular vector as a function of training and de-training

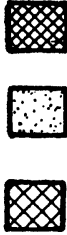

before training $(n=40)$

after three and more years of training $(n=40)$

mares being more than 3 years in breeding (de-training) $(n=20)$

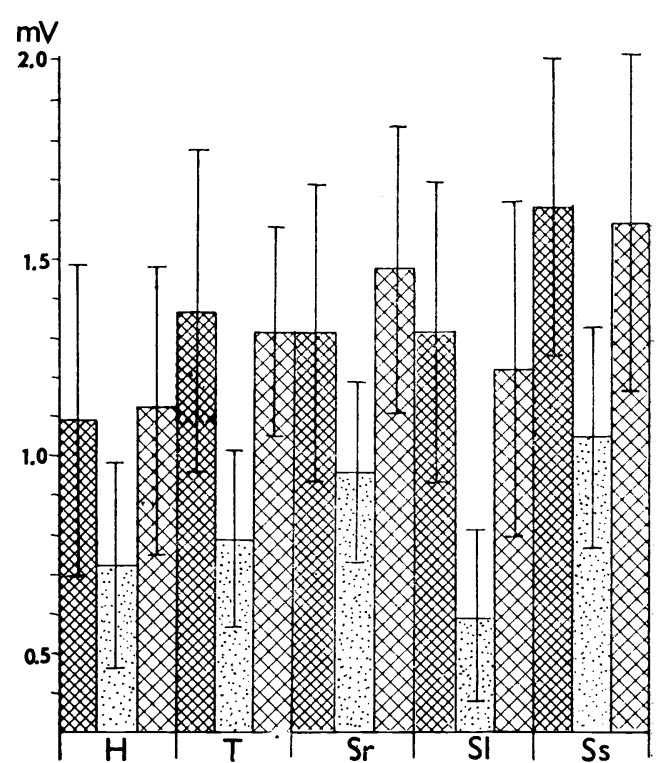


The influence of training and detraining on the value of ventricular vector in 3rd experimental group is shown in Fig 2. It follows from this diagram that training causes the decrease on value of ventricular vector in all planes while detraining of breeding mares leads to reversible increase of this vector. The statistical analysis has revealed that the decrease in ventricular vector value induced by training is highly significant in all tetrahedron planes $(P<0.01)$ as follows from the comparison of non-trained yearlings and trained race horses. The influence of detraining upon the increase of ventricular vector value has proved to be highly significant $(P<0.01)$ as shown on the case of trained race horses and detrained breeding mares. Statistically insignificant differences between non-trained yearlings and detrained breeding mares $(P>0.05)$ are indicative of a great similarity of these two groups as far as ventricular vectors in all tetrahedron planes are concerned.

\section{Discussion}

Training of the race horse more or less decreases the value of ventricular vector depending on individual tetrahedron planes. In comparison with non-trained yearlings the decrease in value of ventricular vector becomes significant in Sl and $T$ planes already after one year of training. After two and more years of training also the value of vector in $\mathrm{H}$ plane becomes finally lower. In the $\mathrm{T}$ plane the decrease in value of this vector as a consequence of training lasting longer than two years is, however, insignificant.

Changes in the value of ventricular vector were, according to Ischikava et al. (1971), attributed to so called Brody-effect. According to this theory the value of ventricular vector depends on the volume of blood in cardiac ventricles and on thickness of ventricular wall. Blood, being a liquid with low specific flow resistance, lowers electromotive forces (vectors) inside ventricles in tangential direction with regard to applied electrodes. That is why the ventricular vector is smaller in the case of dilated heart (greater volume of blood in ventricles) while increasing when the beat volume decreases.

Such cases have been known from the field of human medicine concerned with physical training where e.g. Rouš et al. (1972) reported on the phenomenon of so called sportsman heart occurring in highly efficient individuals which was characterized not only by the hypertrophy of myocardium but also by physiological regulative dilatation of predominantly left ventricle. The regulative dilatation and the increase of beat volume represent compensation mechanism operative in trained individual and functioning to account for increased demands of active tissues for blood supply.

Also in our cases the development of sport-induced regulative dilatation of heart is first of all characterized by the decrease in ventricular vector in all tetrahedron planes observed in all trained race horses while no such phenomenon was observed to occur in non-trained yearling and de-trained breeding mares. The absence of cardiac dilatation in the latter two cases accounts for the similarity of ventricular vectors in these two groups.

The initial training of two-year old horses is predominantly focused to developing fast runners. During this period the horses participate in short distance run competitions $(800-1800 \mathrm{~m})$. This speed work with a predominating oxygen debt represents increased requirements on systemic blood circulation and left heart. The adaptation response to this is regulative dilatation and the increase of beat 
volume namely of the left heart. The vectorcardiographic manifestation of the regulative dilatation of left ventricle after one year of speed training is the decrease in value of ventricular vector in $\mathrm{T}$ and $\mathrm{Sl}$ planes.

In the case of three-year old horses the training is directed towards longer distances namely to classical distances $(2400-2800 \mathrm{~m})$ while 4 and more years old horses are trained for endurance steeple chase $(3200-6900 \mathrm{~m})$. In the latter type of training the aerobic metabolic component becomes more pronounced. This type of energetic coverage increases functional demands not only on left but also on right heart and on pulmonary blood circulation. The adaptation to this type of activity is effected by the development of regulative dilatation and the increase of beat volume of the right heart also. Vectorcardiographic manifestation is represented by the decrease in value of ventricular vector in the Sr plane after two years of training. After three and more years lasting training the regulative cardiac dilatation determines a pronounced decrease in ventricular vector in the $\mathrm{H}$ plane.

The observed results, however, cannot be compared with other authors because so far no reports concerning this topic have appeared. Only in the preceding communication (Hanák 1979) we reported on the decrease in value of ventricular vector in $\mathrm{T}$ and $\mathrm{Ss}$ planes. Together with other electrocardiographic symptoms (delay of intrinsicoid deflexion, QRS complex broadening, higher incidence of deep $Q$ in leads from the left precordium, etc.) the decrease in value of ventricular vector has been connected with the development of so-called sport electrocardiogram of race horses.

\section{Conclusion}

The training of race horse has a significant influence on the value of ventricular vector. The decrease in value of ventricular vector induced by training is due to the development of so-called regulative cardiac dilatation and the increased beat volume. The degree of ventricular vector decrease in individual tetrahedron planes is to great extent dependent on the character of training and exploitation of horses. The of ventricular vector in T and Sl planes after one year's training is due to the predominating left ventricular regulative dilatation which had developed during speed training. The lowering of the vector in $\mathrm{Sr}$, Ss and $\mathrm{H}$ plane following two years and longer training is connected with regulative dilatation of the right ventricle as a consequence of long-distance, endurance training.

\section{Změny komorového vektoru při tréninku plnokrevných dostihových koní}

U 226 plnokrevných koní rozdělených do tří pokusných souborů byl sledován vliv tréninku na velikost komorového vektoru $\mathrm{v} 5$ rovinách tetraedronového svodového systému.

Bylo prokázáno, že trénink koní signifikantně zmenšuje velikost komorového vektoru. Stupeň zmenšení je rozdílný $\mathrm{v}$ jednotlivých rovinách tetraedronu a závislý na charakteru tréninku a sportovní exploataci koní. Zmenšení komorového vektoru je podmíněno vznikem tzv. sportovní regulativní dilatace srdce se zvětšením tepového objemu srdečního. 


\section{Изменения вектора желудочка сердца в ходе тренировки полнокровных скакунов}

На 226 полнокровных скакунов, разделенных в три подопытные группы, проводились исследования влияния тренировок на величину вектора желудочка сердца в 5 уровнях тетраэдрона.

Было установлено, что тренировка лошадей существенно уменьшает величину вектора желудочка. Степень уменьшения отличается разностью в отдельных уровнях тетраэдрона и зависит от характера тренировки и спортивного использования лошадей. Уменьшение вектора желудочка обусловлено возникновением т. н. спортивного регулирующего расширения сердца с увеличением пульсионного объема сердца.

\section{References}

HANÁK, J.: Klinisch-physiologischen Methoden der Verfolgung des Trainings von Rennpferden. Mat. Mezd. kongr. panstw soc. hodowli i prob dzielnosci koni. Warszawa, 1978, 1-26.

HANÁK, J.: Elektrokardiografický svodový systém v diagnostice u plnokrevných koní. Ph. D. Thesis, Brno, 1979, $198 \mathrm{pp}$.

HANÁK, J.: The angle of electrical cardiac axis in trained thoroughbred race horses. Acta vet. Brno, 491980 a: $205-210$.

HANÁK, J.: Bioradiotelemetrie a elektrokardiogram u koní při zátěži. Thesis, Brno, 1980 b, 192, pp.

HANÁK, J. - CHVÁTAL, O. - JANDA, J.: Jednosvodová bipolární elektrokardiografie v hipiatrické diagnostice. Vet. Med., Praha, 21, 1976: 633-640.

HANÁK, J. - JAGOŠ, P.: Vliv věku a tréninku na časový průběh EKG u plnokrevných koní. Vet. Med., Praha, 1980, v tisku.

HANÁK, J. - ŽERT, Z.: Některé znaky EKG plnokrevných koní společné pro rodiče a jeiich potomstvo. Vet. Med. Praha, 1980, v tisku.

ISCHIKAVA, K. - BETSON, H. S. - PIPBERGER, H. V.: Electrocardiographic changes due to cardiac enlargement. Am. Heart J., 84, 1971: 635-642.

MILL, J.: Die Zeitwerte und der Diastolen-Systolen-quotient im Elektrokardiogramm des Sportpferdes und ihre Beziehung zur Leistung. I. Mitteilung: Untersuchungen ohne physische Belastung. Monatshft. f. Veterinärmed., 32, 1977: 861-866.

PERLICK, E.-BÖHME, H.: Elektrokadiographische Untersuchungsmethoden. In Arbeitsmethoden de inneren Medizin. VEB G. Fischer Verlag, Jena, 1967, 100-296.

ROUŠ, J. - BOZDĚCH, Z. - DRAŽIL, V. - KOČNAR, K. - MATĚJKOVÁ, J. - MOUČKOVÁ, J. - NOSOVÁ, T. - PLACHETA, Z. - POKORNÝ, J. - VANK, L.: Tělovýchovné lékařství. SPN Praha, 1972, 176 pp.

STEEL, J. D.: Studies on the electrocardiogram of the racehorse. Austr. Med. Publ. Co., Sydney, 1963, $178 \mathrm{pp}$. 